\title{
Antioxidant Properties and Dominant Bacterial Community of Fermented Rohu (Labeo rohita) Sauce Produced by Enzymatic and Fermentation Method
}

\author{
Siddegowda Gopalapura Shivanne Gowda ${ }^{1}$, Bhaskar Narayan ${ }^{2, *} \mathbb{D}$, Shubha Gopal ${ }^{3}$ \\ ${ }^{1}$ Maharani`s Science College for Women, Department of Microbiology, Mysuru-570 005, India. \\ ${ }^{2}$ CSIR-Central Food Technological Research Institute, Meat and Marine Sciences Department, Mysuru-570 020, India. \\ ${ }^{3}$ University of Mysore, Department of Studies in Microbiology, Mysuru, 570 006, India.
}

\section{Article History}

Received 19 August 2019

Accepted 17 February 2020

First Online 24 February 2020

\section{Corresponding Author}

Tel.: +919448672408

E-mail: advisor.qa@fssai.gov.in

\section{Keywords}

Rohu sauce

Papain

Pediococcus pentosaceus

Antioxidant

Bacterial community

\begin{abstract}
Sauce was produced from Rohu (Labeo rohita) by enzymatic and fermentatively under conditions optimized by response surface method. Salt $(20 \% \mathrm{w} / \mathrm{w})$ and commercial papain $(3 \% \mathrm{w} / \mathrm{w})$ were employed for enzymatic production; while, salt $(25 \%, \mathrm{w} / \mathrm{w})$, sugar $(7.5 \%, \mathrm{w} / \mathrm{w})$ and lactic culture $(10 \%, \mathrm{w} / \mathrm{v}$; Pediococcus pentosaceus FSBP4-40) were used in case of fermentative production. Total antioxidant activity (as ascorbic acid, $\mu \mathrm{g} / \mathrm{ml}$ ), 2,2'-diphenyl-1-picryl-hydrazyl (DPPH, \%) and 2,2'- azinobis-3-ethylbenzothizoline- 6 sulphonate (ABTS; \%) scavenging activities of fermented sauce samples were higher at $3441 \pm 60,49.57 \pm 1.7$ and $99.0 \pm 0.3$, respectively; as compared to enzyme treated samples which showed $803 \pm 13,28.60 \pm 1.1$ and $78.4 \pm 1.0$, for the respective parameters, after 180 days storage at $37^{\circ} \mathrm{C}$. Superoxide anion scavenging activity and reducing potential were found significantly higher $(P<0.05)$ in both fermented as well as enzymatically prepared sauces in comparison to control. Fermented sauce exhibited excellent antibacterial property against Listeria monocytogenes ScottA. Bacterial counts such as total plate count and halophile count, after 180 days, were significantly lower $(P<0.05)$ in the fermentatively produced sauce than enzymatically prepared sauce. Pediococcus, Micrococcus, Enterococcus and Staphylococcus were the dominant bacterial genera in fermented sauce. The study emphasizes the role of accelerating fermentation process, either enzymatically or fermentatively, to produce biofunctionally and bacteriologically superior rohu sauce.
\end{abstract}

\section{Introduction}

With the global fish production reaching 171 million tons in 2016 (FAO, 2018) and fish being considered as one of the important sources of protein, it has become important to look at processes that maintain nutritional value of fish. Fermentation of fish is a safe, environment-friendly and less energy consuming process which is traditionally used to increase shelf-life of fish and to develop fermented fish products (MartiQuijal et al., 2020). Fermented fish products, apart from being an integral part of many food cultures, are also a source of interesting microbes and are an important industry in many countries (Zang et al., 2019). Fish sauce - one of the important fermented fish product - is consumed by over $80-90 \%$ people in Southeast Asia (Longfils et al., 2008). Fish sauce is an amber-colored salty liquid in Southeast Asian cuisine used as an important condiment for improving the taste of foods. There is high divergence in manufacturing among fish sauce-producing countries throughout the world, although the fish and salt are the major raw materials in general production. The leading fish sauce producer in the world is Thailand, with the annual production 
estimated to be $>400$ million litres with 20 out of 100 fish sauce producers contributing more than $80 \%$ of the global production (Vidanarachchi et al., 2014).

The bioactive peptides from fermented fish products have been reported to act as antioxidants (Majumdar et al., 2015). Siddegowda et al., (2016) reviewed that the bioactive peptides may be involved in various biological functions, such as antihypertension, antagonist, immunomodulatory, antithrombotic, antioxidant, anticancer, and antimicrobial activities depending on the amino acid sequences. Aoshima and Ooshima, (2009) studied the antioxidant activity of Japanese liquid condiments, Shoyu (soy sauce) and Gyoshoyu (fish sauce). The in vitro antioxidant properties of the rohu head sauce produced by enzymatic and fermentation method were stated in Siddegowda et al., (2016). Antioxidants are very important for human health, since the production of reactive oxygen species is thought to be a significant cause of aging and carcinogenesis (Lambert and Yang, 2003).

Fish sauces without added starter cultures leads to the growth of halotolerant microorganisms due to the high salt conditions during the natural process of fermentation (Fukui et al., 2012). Various novel halotolerant bacterial cultures have been used to accelerate fermentation process, increase the $\alpha$-amino content, enhance the sensory characteristics, and improve the microbiological quality. The proteolytic enzymes from halotolerant bacteria not only shorten the fermentation period in fish sauce production, but also in turn will help reducing the formation of biogenic amines (Siddegowda et al., 2016). These halotolerant organisms are the source of exogenous proteolytic enzymes, which hydrolyse the fish tissue in the fish sauce fermentation (Jung et al., 2013). Therefore, the study of bacteriological properties to understand the processes involved in fish sauce production has got some significance because the microbial communities reflect the overall quality of the sauce. Biochemical and microbial characteristics of both Ngari and Hentaak traditional fermented fish products of India were analysed by Majumdar et al., (2015). Against this background, the objective of the present study was to compare in vitro antioxidant activities, antibacterial properties and dominant bacterial community in the enzymatically and fermentatively produced fish sauce from rohu.

\section{Materials and Methods}

\section{Materials}

Freshwater fish Rohu (Labeo rohita) was collected from local fish market (Mysore, India) form the material of the study. The material was brought to the laboratory in iced condition. Pediococcus pentosaceus FSBP4-40, a native proteolytic lactic acid bacteria (LAB) starter isolated from salt fermented fish hydrolysate. The protease used for the enzymatic hydrolysis is papain (Loba chemie), 2,2'-diphenyl-1-picrylhydrazyl (DPPH), 2,2 - $\quad$ azinobis-3-ethyl-benzothizoline-6sulphonate (ABTS), peroxidase was purchased from sigma-Aldrich Chemie (Steinheim, Germany). The pathogenic bacterial strains (viz., Micrococcus luteus, Staphylococcus aureus FR1722, Escherichia coli MTCC118, and Listeria monocytogenes Scott A) used for the study of antibacterial activity were from the institute culture collection (CFTRI, Mysuru). Plate count agar (PCA) and brain heart infusion (BHI) were purchased from $\mathrm{M} / \mathrm{s} \mathrm{Hi}$ media Laboratories (Mumbai, India). All the other chemicals used in different analysis were of analytical grade unless otherwise mentioned.

\section{Methods}

\section{Preparation of Rohu Sauce}

The preparation of rohu sauce is schematically represented in Figure 1. Briefly, eviscerated rohu was sliced into small pieces of $2 \times 1 \mathrm{~cm}$ size and washed in potable water 3 times. The sliced rohu was weighed and bottled into clean sterile food grade plastic containers and mixed with commercial enzyme papain ( $3 \%, w / w)$, and was kept at room temperature for $4 \mathrm{~h}$ before adding $20 \%(w / w)$ salt. A control for the enzymatic production of sauce was maintained by adding only salt without papain. The containers were closed with plastic lids and stored at room temperature. P. pentosaceus FSBP 4-40, a proteolytic halotolerant native $L A B$ which was previously isolated from salt fermented fish hydrolysates by our group (GenBank accession no: KU933533) was added (10\%, v/w) along with $7.5 \%, \mathrm{w} / \mathrm{w}$ sugar (dextrose), $2 \%, w / w$ solar salt for fermentative production of rohu sauce. This mixture was incubated for $24 \mathrm{~h}$ at $37^{\circ} \mathrm{C}$ and remaining salt of $23 \%, w / w$ was added to make up the total salt concentration of $25 \%$, $w / w$. Fish with salt without added LAB was the control for the fermentation method. The liquid was filtered through cheese-cloth at every $15 \mathrm{~d}$ till 6 months and further filtered using Whatman no. 1 filter paper. The resulted liquid was considered as fish sauce and the yield of the same was measured as the ratio of original fish-salt and papain mass in the container to the weight of liquid after filtration. The fish sauce was lyophilized and used for in vitro antioxidant activity and antibacterial property.

\section{Antioxidant Properties of Fermented Rohu Sauce}

\section{Preparation of Sample}

Fish sauce samples were dissolved $(50 \mathrm{mg} / \mathrm{ml})$ in double distilled water and homogenized at $10000 \mathrm{rpm}$ for 2 min using homogenizer (Polytron PT 3100) followed by centrifugation at $7000 \times \mathrm{g}$ for $15 \mathrm{~min}$. The supernatant was collected and filter through Whatman No. 1 filter paper and protein content in the filtrate was 


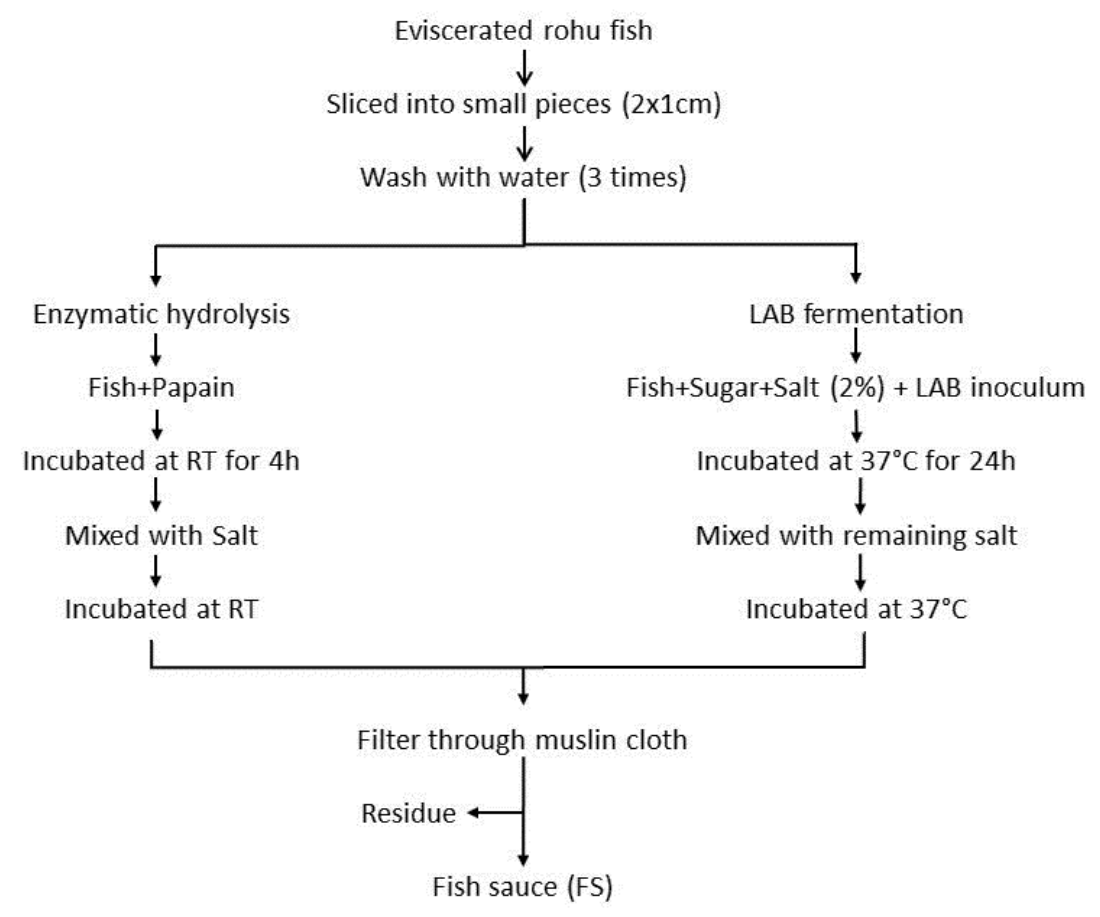

Figure 1. Schematic flow of sauce production from Rohu (Labeo rohita) using papain and P. pentosaceus FSBP4-40.

estimated by the method of Lowry et al., (1951). This filtrate was used for assaying various antioxidant activities.

\section{Antioxidant Properties}

\section{Total Antioxidant Activity}

The Total antioxidant activity (TAO) of fermented fish sauce sample was determined according to the method of Prieto et al., (1999). Briefly, $0.3 \mathrm{~mL}$ of sample was mixed with $3.0 \mathrm{~mL}$ reagent solution (1:1:1, v/v of 0.6 $\mathrm{M}$ sulphuric acid, $28 \mathrm{mM}$ sodium phosphate and $4 \mathrm{mM}$ ammonium molybdate). Reaction mixture was heated at $95^{\circ} \mathrm{C}$ for $90 \mathrm{~min}$ in a water bath, cooled to room temperature. Absorbance of all the sample mixtures was measured at $695 \mathrm{~nm}$ and TAO was expressed as of ascorbic acid equivalents in micrograms per gram of sample.

\section{DPPH Radical Scavenging Activity}

The DPPH radical scavenging capacity of fish sauce samples was determined by the method described in Bijinu et al., (2011). Briefly, $2.0 \mathrm{~mL}$ of $0.16 \mathrm{mM}$ DPPH solution (in methanol) was added to the test tube containing $100 \mu \mathrm{L}$ of sample and made up to $2 \mathrm{~mL}$ with distilled water. The mixture was vortexed for $1 \mathrm{~min}$ and kept at room temperature for $30 \mathrm{~min}$ in dark. Sample blank was prepared by replacing DPPH with methanol and methanol along with DPPH served as positive control. The scavenging activity (\%) was determined by measuring the absorbance of samples at $517 \mathrm{~nm}$ and calculated using the formula:

$$
\begin{gathered}
\text { Scavenging activity }(\%)= \\
{\left[1-\left\{\left(A_{\text {sample }}-A_{\text {sample balnk }}\right) / A_{\text {control }}\right\}\right] \times 100}
\end{gathered}
$$

\section{Super Oxide Scavenging Activity}

Super oxide anion scavenging activity of the samples was determined by the method as described in Heo et al., (2005). An aliquot of $100 \mu \mathrm{L}$ was made up to $0.3 \mathrm{~mL}$ and added with $2.6 \mathrm{~mL}$ of $50 \mathrm{mM}$ phosphate buffer ( $\mathrm{pH} 8.2$ ), to this $90 \mu \mathrm{L}$ of freshly prepared $3 \mathrm{mM}$ pyrogallol dissolved in $10 \mathrm{mM} \mathrm{HCl}$ was added. Sample blank was prepared by mixing $0.3 \mathrm{~mL}$ of distilled water in $2.6 \mathrm{~mL}$ of phosphate buffer. The absorbance was measured at $325 \mathrm{~nm}$ from $0 \mathrm{~min}$ and $10 \mathrm{~min}$.

\section{ABTS Radical Scavenging Activity}

ABTS radical scavenging activity of the samples was carried out as explained in Sachindra and Bhaskar (2008). ABTS radical solution was prepared by mixing ready to use $A B T S$ solution with $100 \mathrm{~mL}$ of $0.05 \mathrm{M}$ acetate buffer $(\mathrm{pH} 4.5)$ and 5 units of peroxidise and incubated at $37^{\circ} \mathrm{C}$ for $15 \mathrm{~h}$. ABTS $(1.9 \mathrm{~mL})$ was mixed with $0.1 \mathrm{~mL}$ sample and incubated at $37^{\circ} \mathrm{C}$ for $1 \mathrm{~h}$. Buffer instead of ABTS served as sample blank and distilled water $(0.1 \mathrm{~mL})$ instead of sample was used as control. Scavenging activity was calculated as follows:

$$
\begin{gathered}
\text { Scavenging activity }(\%)= \\
{\left[1-\left\{\left(A_{\text {sample}}-A_{\text {sample balnk }}\right) / A_{\text {control }}\right\}\right] \times 100}
\end{gathered}
$$




\section{Reducing Power Assay}

Reducing potential of the fermented fish sauce samples was assayed by the method as followed in Bijinu et al., (2011) and absorbance was measured at different concentration (50, 100, 150 and $200 \mu \mathrm{L}$ ). Briefly, samples at different concentrations were mixed with $2.5 \mathrm{~mL}$ of $0.2 \mathrm{M}$ phosphate buffer $(\mathrm{pH} 6.6)$ and 2.5 $\mathrm{mL}$ of $1 \%$ potassium ferricyanide. Reaction mixture was incubated at $50^{\circ} \mathrm{C}$ for $20 \mathrm{~min}$ and $2.5 \mathrm{~mL}$ of $10 \%$ trichloroacetic acid was added, centrifuged at $8000 \mathrm{rpm}$ for $10 \mathrm{~min}$. From the upper layer of the solution, $2.5 \mathrm{~mL}$ was taken for further reaction and mixed with $2.5 \mathrm{~mL}$ of distilled water and $0.5 \mathrm{~mL}$ of $0.1 \%$ ferric chloride. Absorbance of all the samples was measured at $700 \mathrm{~nm}$ by using distilled water as blank.

\section{Antibacterial Properties}

The antibacterial activity of fermented fish sauce samples was assayed by the agar well diffusion method (Geis et al., 1983). Selected human bacterial pathogens were overlaid on nutrient agar with brain heart infusion (BHI) soft agar (0.8\%) and allowed to grow at $37^{\circ} \mathrm{C}$ for 4 $6 \mathrm{~h}$. Fish sauce samples for antibacterial activity were prepared by dissolving $50 \mathrm{mg} / \mathrm{ml}$ sample in sterilized double distilled water and homogenized at $10000 \mathrm{rpm}$ for 2 min using homogenizer (Polytron PT 3100) followed by centrifugation at $7000 \times \mathrm{g}$ for $15 \mathrm{~min}$. The resultant supernatant was added in a concentration of $50 \mu \mathrm{l}$ into wells made on the plates containing pathogenic strains. The plates were then pre-incubated for $2-3 \mathrm{~h}$ at $4^{\circ} \mathrm{C}$ to allow the test material to diffuse into the agar and later they were incubated at $37^{\circ} \mathrm{C}$ a further for $18 \mathrm{~h}$. The antibacterial spectrum of the samples was determined by measuring the diameter of the inhibition zones in $\mathrm{mm}$.

\section{Microbiological Analysis}

In order to identify dominant microflora associated with fermentation, microbial load of fermented rohu sauce samples was determined monthly from day-1 to $180 \mathrm{~d}$ using standard methods (APHA 2001). Ten grams of sample was diluted in $90 \mathrm{ml}$ of sterile physiological saline and then mixed by stomacher blender (Stomacher 400) for $2 \mathrm{~min}$, the stock was then 10-fold serially diluted in sterile saline and $0.1 \mathrm{ml}$ of each proper diluted sample was spread with glass spreader on media plates for obtaining total plate count. The inoculated plates were incubated at $37{ }^{\circ} \mathrm{C}$ for $24-48$ hours. Plate count agar with $10 \%(\mathrm{w} / \mathrm{w}) \mathrm{NaCl}$ was used for determining total halophiles count and the plates were incubated at 37으 for 10 days. Microbial count was expressed in log CFU/g. The dominant bacterial colonies were randomly selected by their similarity in morphological properties from the total plate count agar plates and biochemically characterized as per the protocol outlined in Bergey's manual of determinative bacteriology (Bergey et al., 2002).

\section{Results}

\section{Antioxidant Activity of Fermented Rohu Sauce}

In vitro antioxidant activities such as TAO activity and ABTS radical scavenging activity of lyophilized powder are presented in the Table 1 . Sauce samples inoculated with LAB ( $P$. pentosaceus FSBP4-40) had better TAO activity and ABTS radical scavenging activity compared to the papain treated samples. There was 10fold and 3-fold increase in TAO activity of LAB fermented and enzyme treated sauce samples, respectively than control at the end of $180 \mathrm{~d}$. Initially, the TAO activity (Eq to ascorbic acid, $\mu \mathrm{g} / \mathrm{ml}$ ) of LAB fermented sauce sample was $1374 \pm 43$ and reached $3441 \pm 60$ towards the end of the fermentation. Almost maximum ABTS radical scavenging activity was exhibited by $L A B$ treated sample at the $180 \mathrm{~d}$. The ferric chloride reducing power of both treated and untreated samples are given in the Table 2. Higher ferric chloride reducing power was noticed in $P$. pentosaceus FSBP4-40 treated sauce sample than the control and enzyme treated samples. Over 3-fold increase in ferric chloride reducing power was observed in LAB fermented sauce than the enzyme treated sauce at all different concentrations of samples towards the end of $180 \mathrm{~d}$. The sauce produced by fermentative method exhibited higher DPPH radical scavenging activity as compared to the enzyme treated and control after $180 \mathrm{~d}$ of storage (Figure 2A). The DPPH radicals

Table 1. Total antioxidant activity and ABTS scavenging activity of papain treated and LAB treated rohu sauce during fermentation

\begin{tabular}{lcccccc}
\hline & \multicolumn{3}{c}{ TAO (Eq to ascorbic acid, $\mu \mathrm{g} / \mathrm{ml}$ ) } & \multicolumn{3}{c}{ ABTS Scavenging (\%) } \\
\cline { 2 - 7 } Day & $\mathrm{C}$ & $\mathrm{PT}$ & $\mathrm{LT}$ & $\mathrm{C}$ & \multicolumn{1}{c}{ PT } & LT \\
\hline 1 & $208 \pm 15^{\mathrm{b}}$ & $604 \pm 30^{\mathrm{a}}$ & $1374 \pm 43^{\mathrm{a}}$ & $58.7 \pm 1.4^{\mathrm{a}}$ & $65.5 \pm 1.4^{\mathrm{a}}$ & $78.7 \pm 0.6^{\mathrm{a}}$ \\
30 & $382 \pm 60^{\mathrm{d}}$ & $674 \pm 80^{\mathrm{b}}$ & $2271 \pm 52^{\mathrm{b}}$ & $65.0 \pm 1.4^{\mathrm{b}}$ & $70.9 \pm 0.7^{\mathrm{b}}$ & $87.4 \pm 0.6^{\mathrm{b}}$ \\
60 & $374 \pm 16^{\mathrm{d}}$ & $722 \pm 30^{\mathrm{c}}$ & $2200 \pm 57^{\mathrm{b}}$ & $60.7 \pm 2.1^{\mathrm{a}}$ & $74.8 \pm 0.7^{\mathrm{c}}$ & $89.3 \pm 0.3^{\mathrm{c}}$ \\
90 & $317 \pm 30^{\mathrm{c}}$ & $776 \pm 11^{\mathrm{d}}$ & $2423 \pm 90^{\mathrm{c}}$ & $58.7 \pm 2.1^{\mathrm{a}}$ & $72.6 \pm 1.0^{\mathrm{b}, \mathrm{c}}$ & $93.3_{0.6^{\mathrm{d}}}$ \\
120 & $275 \pm 30^{\mathrm{b}}$ & $739 \pm 24^{\mathrm{c}}$ & $2908 \pm 12^{\mathrm{d}}$ & $59.0 \pm 1.0^{\mathrm{a}}$ & $73.3 \pm 1.4^{\mathrm{b}, \mathrm{c}}$ & $92.5 \pm 0.6^{\mathrm{d}}$ \\
150 & $229 \pm 10^{\mathrm{a}}$ & $734 \pm 20^{\mathrm{c}}$ & $3223 \pm 18^{\mathrm{e}}$ & $57.0 \pm 1.7^{\mathrm{a}}$ & $72.3 \pm 2.1^{\mathrm{b}, \mathrm{c}}$ & $97.7 \pm 0.3^{\mathrm{e}}$ \\
180 & $314 \pm 12^{\mathrm{c}}$ & $803 \pm 13^{\mathrm{d}}$ & $3441 \pm 60^{\mathrm{f}}$ & $65.5 \pm 2.7^{\mathrm{b}}$ & $78.4 \pm 1.0^{\mathrm{d}}$ & $99.0 \pm 0.3^{\mathrm{f}}$ \\
\hline
\end{tabular}

Values in column are mean \pm SD, C-control, PT-papain treated, and LT-LAB treated. Different superscripts, column-wise, indicate statistically significant differences $(P<0.05)$. 
Table 2. Reducing potential of papain treated and LAB treated rohu sauce during fermentation

\begin{tabular}{|c|c|c|c|c|c|c|c|c|c|c|c|c|}
\hline \multirow[b]{2}{*}{ DAY } & \multicolumn{4}{|c|}{ C } & \multicolumn{4}{|c|}{ PT } & \multicolumn{4}{|c|}{ LT } \\
\hline & $25 \mu \mathrm{l}$ & $50 \mu \mathrm{l}$ & $75 \mu \mathrm{l}$ & $100 \mu \mathrm{l}$ & $25 \mu \mathrm{l}$ & $50 \mu \mathrm{l}$ & $75 \mu \mathrm{l}$ & $100 \mu \mathrm{l}$ & $25 \mu \mathrm{l}$ & $50 \mu \mathrm{l}$ & $75 \mu \mathrm{l}$ & $100 \mu \mathrm{l}$ \\
\hline 1 & $0.05 \pm 0^{\mathrm{a}}$ & $0.10 \pm 0^{2}$ & $0.15 \pm 0^{\mathrm{a}}$ & $0.20 \pm 0^{\mathrm{a}, \mathrm{b}}$ & $0.06 \pm 0^{2}$ & $0.15 \pm 0^{\mathrm{a}}$ & $0.19 \pm 0^{\mathrm{a}}$ & $0.26 \pm 0^{\mathrm{a}}$ & $0.24 \pm 0^{\mathrm{a}}$ & $0.43 \pm 0^{2}$ & $0.62 \pm 0^{2}$ & $0.83 \pm 0^{\mathrm{a}}$ \\
\hline 30 & $0.07 \pm 0^{\mathrm{h}}$ & $0.15 \pm 0^{\mathrm{b}, \mathrm{c}}$ & $0.23 \pm 0^{c}$ & $0.28 \pm 0$ & $0.11 \pm 0^{\mathrm{b}, \mathrm{c}}$ & $0.18 \pm 0^{a, b}$ & $0.27 \pm 0^{\mathrm{h}}$ & $0.34 \pm 0^{\mathrm{bh}}$ & $0.34 \pm 0^{\mathrm{h}}$ & $0.63 \pm 0^{\mathrm{h}}$ & $0.88 \pm 0^{\mathrm{b}}$ & $1.27 \pm 0^{\mathrm{h}}$ \\
\hline 60 & $0.08 \pm 0^{\mathrm{h}}$ & $0.15 \pm 0$ & $0.22 \pm 0=$ & $0.28 \pm 0=$ & $0.10 \pm 0^{\mathrm{h}}$ & $0.18 \pm 0^{\mathrm{h}}$ & $0.28 \pm 0^{\mathrm{h}}$ & $0.38 \pm 0=$ & $0.41 \pm 0^{c}$ & $0.69 \pm 0^{=}$ & $0.99 \pm 0=$ & $1.37 \pm 0 c$ \\
\hline 90 & $0.07 \pm 0^{a, b}$ & $0.12 \pm 0^{\mathrm{a}}$ & $0.19 \pm 0^{\mathrm{bc}}$ & $0.29 \pm 0=$ & $0.12 \pm 0^{b, c}$ & $0.22 \pm 0=$ & $0.33 \pm 0^{c, d}$ & $0.43 \pm 0^{d}$ & $0.56 \pm 0^{d}$ & $0.89 \pm 0^{d}$ & $1.20 \pm 0^{d}$ & $1.54 \pm 0^{d}$ \\
\hline 120 & $0.05 \pm 0^{\mathrm{a}}$ & $0.12 \pm 0^{\mathrm{a}}$ & $0.17 \pm 0^{\text {sh }}$ & $0.22 \pm 0^{\mathrm{h}}$ & $0.11 \pm 0^{b, c}$ & $0.23 \pm 0^{c, d}$ & $0.32 \pm 0=$ & $0.40 \pm 0$ & $0.66 \pm 0^{\circ}$ & $0.91 \pm 0^{=}$ & $1.30 \pm 0^{\circ}$ & $1.61 \pm 0^{2}$ \\
\hline 150 & $0.06 \pm 0^{\mathrm{a}, \mathrm{b}}$ & $0.13 \pm 0^{a, b}$ & $0.15 \pm 0^{\mathrm{a}}$ & $0.18 \pm 0^{\mathrm{a}}$ & $0.12 \pm 0^{\mathrm{b}, \mathrm{c}}$ & $0.23 \pm 0^{c, d}$ & $0.34 \pm 0^{c, d}$ & $0.43 \pm 0^{d}$ & $0.80 \pm 0^{f}$ & $1.19 \pm 0^{f}$ & $1.43 \pm 0^{f}$ & $1.77 \pm 0^{f}$ \\
\hline 180 & $0.08 \pm 0^{\mathrm{b}}$ & $0.16 \pm 0=$ & $0.22 \pm 0=$ & $0.31 \pm 0=$ & $0.13 \pm 0^{k}$ & $0.25 \pm 0^{d}$ & $0.35 \pm 0^{d}$ & $0.47 \pm 0^{\circ}$ & $0.89 \pm 05$ & $1.22 \pm 05$ & $1.56 \pm 05$ & $1.97 \pm 05$ \\
\hline
\end{tabular}

Values in column are mean \pm SD, C-control, PT-papain treated and LT-LAB treated. Different superscripts, column-wise, indicate statistically significant differences $(\mathrm{P}<0.05)$.
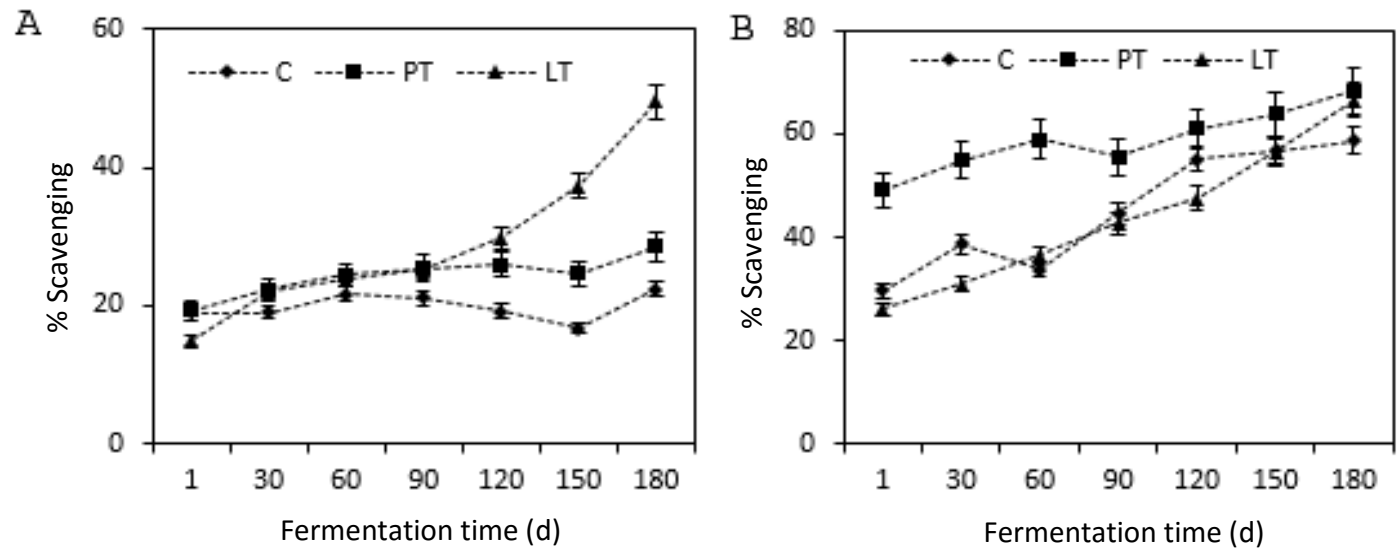

Figure 2. DPPH (A) and Superoxide (B) scavenging activity of papain treated and LAB treated rohu sauce during fermentation.

scavenging activity of $L A B$ and papain treated sauce samples were $49.57 \pm 1.7 \%$ and $28.60 \pm 1.1 \%$, respectively. The superoxide radicals scavenging activity of papain treated sample was slightly higher $(68.40 \pm 1.0 \%)$ than LAB treated $(66.50 \pm 0.8 \%)$ sample towards the end of fermentation period (Figure $2 B$ ). Overall, the antioxidant activities of LAB ( $P$. pentosaceus FSBP4-40) treated samples were higher compared to papain treated samples except superoxide scavenging activity.

\section{Antibacterial Properties of Fermented Rohu Sauce}

Fermented rohu sauce produced using $P$. pentosaceus FSBP4-40 showed higher antibacterial activity against pathogen $L$. monocytogenes Scott A (Table 3). The enzyme treated and LAB fermented sauce samples shown the inhibition zone diameter of $16.0 \pm 0.0$ $\mathrm{mm}$ and $26.5 \pm 2.1 \mathrm{~mm}$, respectively. There was a marginal difference in the antibacterial activity of enzyme treated sample with that of untreated sauce samples. The antibacterial activity of papain treated and LAB fermented sauce samples exhibited slightly higher than the untreated sauce sample against Micrococcus luteus, Staphylococcus aureus FR1722 and Escherichia coli MTCC118.

\section{Bacteriological Properties of Fermented Rohu Sauce}

In the initial stages of the fermentation, total plate count of the treated and untreated samples of rohu sauce were in the range of $7.48 \pm 0.5$ to $7.58 \pm 0.1$ log $\mathrm{cfu} / \mathrm{ml}$ (Figure 3A). There was gradual decrease in the count of treated samples and no bacterial load was found at the end of fermentation. The untreated rohu sauce showed $7.48 \pm 0.1 \mathrm{log} \mathrm{cfu} / \mathrm{ml}$ after $180 \mathrm{~d}$ and the count was not detected after $150 \mathrm{~d}$ in LAB fermented rohu sauce. Almost continuous increase in log $\mathrm{cfu} / \mathrm{ml}$ values of halophiles was observed in untreated rohu sauce samples throughout the storage period (Figure $3 \mathrm{~B})$. The same trend was noticed in papain treated sauce with slight decrease in count at day-60 and day-90 but, the count was not detected day-30 onwards in LAB fermented samples. The study revealed that the total plate count and halophile count of the papain treated and untreated samples were almost equivalent range towards the end of storage. Overall, the bacteriologically quality of sauce produced using $P$. pentosaceus FSBP4-40 was superior to enzymatically produced sauce. 
Table 3. Antibacterial activity of papain and LAB treated rohu sauce after $180 \mathrm{~d}$ of fermentation

\begin{tabular}{|c|c|c|c|}
\hline \multirow[b]{2}{*}{ Pathogens } & \multicolumn{3}{|c|}{ Rohu sauce } \\
\hline & $\mathrm{C}$ & PT & $\mathrm{LT}$ \\
\hline Micrococcus luteus & $11.5 \pm 2.1^{\mathrm{a}}$ & $14.0 \pm 1.4^{\mathrm{a}}$ & $14.5 \pm 0.7^{a}$ \\
\hline Staphylococcus aureus FR1722 & $11.5 \pm 0.7^{a}$ & $15.0 \pm 0.0^{a, b}$ & $14.5 \pm 2.1^{\mathrm{a}}$ \\
\hline Escherichia coli MTCC118 & $12.0 \pm 1.4^{\mathrm{a}}$ & $14.0 \pm 0.0^{\mathrm{a}}$ & $14.0 \pm 2.8^{a}$ \\
\hline Listeria monocytogenes Scott A & $14.0 \pm 2.8^{\mathrm{a}}$ & $16.0 \pm 0.0^{c}$ & $26.5 \pm 2.1^{b}$ \\
\hline
\end{tabular}

Values (inhibition zone diameter in $\mathrm{mm}$ ) in column are mean \pm SD. C-control, PT-papain treated and LT-LAB treated. Different superscripts, columnwise, indicate statistically significant differences $(P<0.05)$
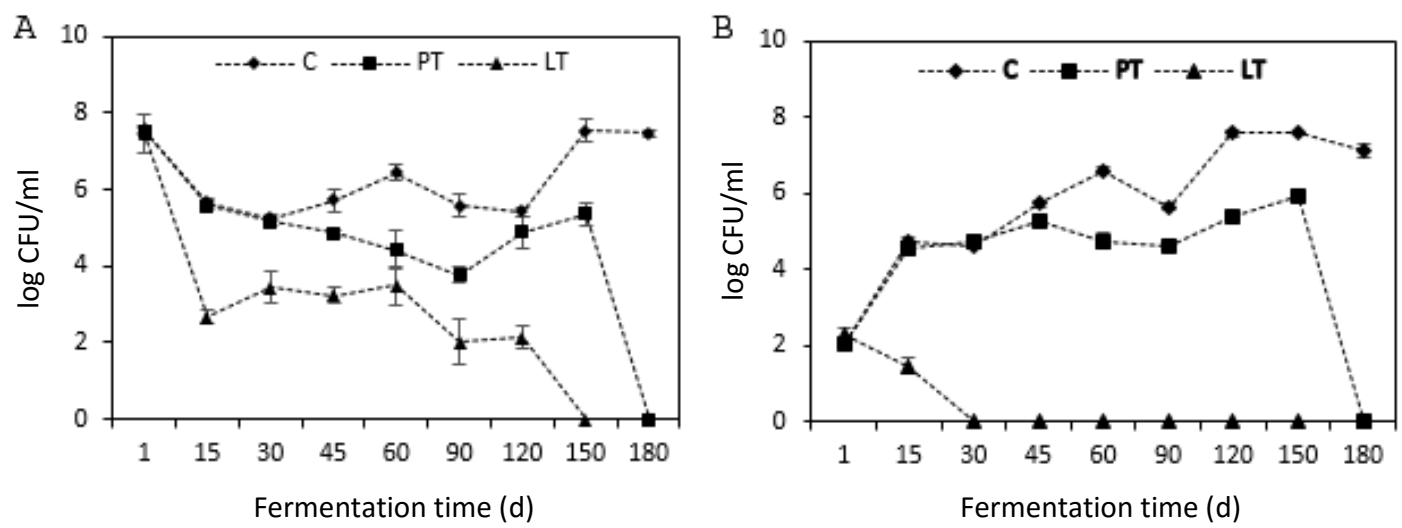

Figure 3. Total plate count (A) and Halophile count (B) of papain treated and LAB treated rohu sauce during fermentation

\section{Dominant Bacterial Community in Fermented Rohu Sauce}

The dominant bacterial colonies were randomly selected from fish sauce by their similarity in morphological characteristics from the total plate count plates. The details of biochemical characteristics of dominant bacterial groups isolated are presented in Table 4. Morphologically, the isolates were spherical in shape and Gram positive. Of the four isolates two isolates were positive for catalase activity and three isolates were oxidase positive. They exhibit potential lipolytic and proteolytic activities. The isolates grown at different $\mathrm{pH}$, temperature and showed tolerance towards wide range of salt concentration. As per the Bergey's manual of determinative bacteriology the isolates were characterized as Pediococcus, Micrococcus, Enterococcus and Staphylococcus. These were the bacterial genera associated in the fermented rohu sauce predominantly throughout the fermentation period.

\section{Discussion}

The studies have shown that uncontrolled free radicals including hydroxyl radicals, peroxyl radicals, 1,1diphenyl-2-picrylhydrazyl (DPPH) radical and superoxide anion radical can attack various tissue components leading to autoimmune diseases, neurodegenerative disorders and cancers (Kehrer and Klotz, 2015).
Fermented fish products could be used as a potential source of nutrients and natural antioxidants (Majumdar et al., 2016). In vitro TAO activity of fermented rohu sauce is in agreement with the results of Siddegowda et al., (2016). They stated that the LAB fermented rohu head sauce exhibited higher TAO (ascorbic acid equivalents in $\mu \mathrm{g} \mathrm{g}^{-1}$ ) activity of $1236.25 \pm 7.07$ than the enzyme treated sauce $(1070.63 \pm 11.49)$ towards end of $120 \mathrm{~d}$ of storage. Whereas, the ABTS scavenging activity of both enzyme and $L A B$ treated rohu head sauce samples were almost identical at the end of fermentation. Peralta et al. (2008) reported that the Philippine's salt fermented shrimp paste showed 24.3 $61.5 \%$ of DPPH radical scavenging activity in $80 \%$ ethanolic extract. Aoshima and Ooshima, (2009) showed that the DPPH radical-scavenging activity of Japanese fish sauce Gyoshoyu (87.7 $\pm 0.1 \%)$ was greater than the soy sauce Shoyu (32.3 $\pm 3.7 \%)$. Gyoshoyu is also useful for reducing level of $\mathrm{H}_{2} \mathrm{O}_{2}$ in foods, when it is added as a liquid condiment. This anti hydrogen peroxide activity of Gyoshoyu is due to the presence of a thermostable catalase. The peptides from fermented fish products have been reported to act as antioxidants (Majumdar et al., 2015). Antioxidative peptides were isolated and characterized from fish sauce by-product, a solid waste generated in fish sauce industry contains natural protein hydrolysates produced from digestion of fish proteins using various protease and halophiles in the fermentation (Choksawangkarn et al., 2018). The study evidenced that the fish sauce by-product contained a 
Table 4. Characteristics of dominant bacterial community in fermented rohu sauce

\begin{tabular}{|c|c|c|c|c|}
\hline Characteristics & Isolate-1 & Isolate-2 & Isolate-3 & Isolate-4 \\
\hline Colour & White & Yellow & White & White \\
\hline Cell morphology & Cocci & Cocci & Cocci & Cocci \\
\hline Gram staining & + & + & + & + \\
\hline Catalase & - & + & + & - \\
\hline Oxidase & + & + & - & + \\
\hline Lipase & - & + & + & + \\
\hline Protease & + & - & + & + \\
\hline Growth at $\mathrm{pH} 4.2$ & + & - & + & - \\
\hline 7.5 & + & + & + & + \\
\hline 8.5 & + & + & + & + \\
\hline Growth at $10 \circ \mathrm{C}$ & - & + & - & - \\
\hline $30 \circ \mathrm{C}$ & + & + & + & + \\
\hline $50 \circ \mathrm{C}$ & + & - & + & - \\
\hline Growth at $0 \%$ Salt & + & + & + & + \\
\hline $3.0 \%$ Salt & + & + & + & + \\
\hline $6.5 \%$ Salt & + & + & + & + \\
\hline $9.0 \%$ Salt & - & + & + & - \\
\hline \multicolumn{5}{|l|}{ Sugar utilization } \\
\hline Maltose & + & + & + & + \\
\hline Lactose & - & + & - & + \\
\hline Mannitol & - & + & - & + \\
\hline Sucrose & + & + & - & + \\
\hline Sorbitol & - & + & + & - \\
\hline Glucose & + & + & - & + \\
\hline Dextrose & + & + & + & + \\
\hline Species of genus & Pediococcus & Micrococcus & Staphylococcus & Enterococcus \\
\hline
\end{tabular}

high amount of low molecular weight proteins/peptides and had most potent antioxidant activity. The proteins present in the raw material (rohu) are hydrolysed into peptides and amino acids during fermentation. These protein hydrolysates in the sauce might be responsible for antioxidant activity. Some of these bioactive peptides have demonstrated multifunctional activities such as immunomodulatory, anticancer and antimicrobial activities along with the antioxidant properties based on their structure and other factors, including hydrophobicity, charge, or microelement binding properties (Siddegowda et al., 2016).

The shelf-life of the LAB fermented food products was enhanced by maintaining the acidic condition due to lactic acid produced by LAB and their antagonistic nature towards food spoilage and food poisoning bacteria (Hwanhlem et al., 2011). The antibacterial activity exhibited by the fish sauce samples could be due to the presence of antimicrobial peptides (bacteriocin) as well as protein hydrolysates produced during fermentation (Amit et al., 2011). The hydrolysates of food proteins by intestinal proteases have also been shown to be antibacterial as well as immunostimulatory in nature (Gediminas et al., 2006). Selected strains of lactic acid bacteria isolated and screened from Thai traditional fermented fish (pla-som) showed excellent antagonistic activity against Escherichia coli, Staphylococcus aureus, and Salmonella sp. (Hwanhlem et al., 2011).

Jiang et al., (2007) reported that, the higher microbial counts in the early stages of the fermentation were due to incomplete dissolution and improper penetration of salt into the fish and survival of nonhalotolerant bacteria on fish flesh. Kilinc et al., (2006) testified that, the initial and final total viable counts of sardine fermented fish sauce produced at different concentrations of sodium chloride and glucose at $37 \circ \mathrm{C}$ for $57 \mathrm{~d}$ were in the range of $3.95 \pm 0.05$ to $4.47 \pm 0.08 \mathrm{log}$ $\mathrm{cfu} / \mathrm{g}$ and $3.93 \pm 0.05$ to $5.64 \pm 0.09 \mathrm{log} \mathrm{cfu} / \mathrm{g}$, respectively. In mahyaveh, a traditional Iranian fish sauce the mean value (log cfu/g) for aerobic mesophilic count was $4.71 \pm 3.65$ in the sauce samples collected from five different locations in the Southern part of Iran (Zarei et al., 2012). A little decrease in the bacterial counts was reported during fermentation of low salt fish sauces produced from squid processing byproducts ( $\mathrm{Xu}$ et al., 2008). Majumdar et al., (2015) revealed that, the total plate count of Ngari and Hentaak- traditional fermented fish products of India were $6.65 \pm 1.00 \mathrm{log} \mathrm{cfu} / \mathrm{g}$ and $7.81 \pm 0.09 \log \mathrm{cfu} / \mathrm{g}$, respectively.

Decreased counts of halophilic bacteria within $30 \mathrm{~d}$ of fermentation were reported in fish sauce samples prepared from anchovy hydrolysates inoculated with bacterial starter cultures (Yongsawatdigul et al., 2007). The bacterial counts on plate count agar containing $18 \%$ $\mathrm{NaCl}$ were not detected after $60 \mathrm{~d}$ and $90 \mathrm{~d}$ in the fish sauce samples inoculated with Staphylococcus sp. CMS5-7-5 and CMC5-3-1, respectively (Udomsil et al., 2015). Ibrahim, (2010) evaluated the microbial properties of fish sauce produced from Gambusia (Affinis affinis) with salt content of $25 \%(\mathrm{w} / \mathrm{w})$ for 5 months and stated that, the log cfu/ml values for total 
plate count, halophilic count were 2.0 \pm 0.06 and $2.30 \pm 0.11$, respectively. Faisal et al., (2015) discussed that, in the initial stage of fish sauce fermentation Micrococcus, Lactobacillus, Corynebacterium, Escherichia coli, Streptococcus and Pseudomonas were detected. As the fermentation progresses Corynebacterium, E.coli, Streptococcus failed to survive due to the high salt concentration and at the end of 9 months, the dominant salt tolerant bacteria survived and multiplied are Bacillus, Micrococcus, Lactobacillus and Pseudomonas. Paludan-Muller et al. (2002) have reported that the halotolerant bacteria will grow and propagate after 5 days of fermentation and these halophiles mostly were $L A B$ and yeasts.

The dominant bacterial genera in fermented rohu sauce are in correlation with the findings of Majumdar et al., (2015). The study reported that Micrococcus and Staphylococcus were the dominant bacterial genera associated with Ngari and Hentaak, the traditional fermented fish products of India. Some of the species of these genera effectively hydrolyse the proteins with their proteolytic potentiality and utilize lipids by their lipolytic property (Jini et al., 2011). Lactobacillus plantarum and Enterococcus faecium were the dominant lactic acid bacteria isolated from a traditional fermented fish sauce mahyaveh. These bacteria play a significant role in promoting the quality and safety and also develop organoleptic properties of fermented foods (Karparvar et al., 2019). Previous studies have also shown that species of Staphylococcus, Micrococcus, Lactobacillus and Tetragenococcus were the dominant bacterial community associated during the fish sauce fermentation (Lee et al., 2015; Faisal et al., 2015). Few of the species of Staphylococcus Virgibacillus and Tetragenococcus were employed as starter cultures in the acceleration of fish sauce production and improvement of sauce quality (Yongsawatdigul et al., 2007: Udomsil et al., 2011). According to Lopetcharat and Park, (2002), Micrococcus, Staphylococcus and Bacillus were the dominant bacterial community during the fermentation of fish sauce. Bacterial community dynamics of myeolchi-aekjeot, a Korean traditional fermented fish sauce initially dominated with the bacterial genera Phychrobacter, Photobacterium and Vibrio, disappear rapidly and Salinivibrio, Staphylococcus and Tetragenococcus appeared as major populations in the later stages of fermentation (Lee et al., 2015). The fermentative properties of Pediococcus acidilactici $\mathrm{K} 7$ and Enterococcus faecium HAB01 were exploited for the recovery of oil from freshwater fish viscera (Amit et al., 2010). Siddegowda et al., (2016) reported that, the Pediococcus strains with potential proteolytic and fermentative properties were the predominant lactic acid bacteria in salt fermented fish hydrolysate prepared using freshwater fish rohu (Labeo rohita). Based on the biochemical criteria, nutritional value and microbial aspects Ibrahim, (2010) suggested that the fish sauce is safe for human consumption as it is rich in protein and essential amino acids.

\section{Conclusion}

The study suggested that an accelerated fermentation of rohu, a freshwater fish into fish sauce with acceptable biofunctional quality in terms of nutrition using papain and native halotolerant, proteolytic lactic acid bacteria. In vitro antioxidant activities of $P$. pentosaceus FSBP4-40 fermented sauce exhibited superiority over enzyme treated sauce samples. LAB treated sauce showed higher antibacterial activity against pathogen $L$. monocytogenes Scott $A$. The microbiological quality of the sauce produced from fermentative method appeared to be better than the enzymatically produced sauce. Pediococcus, Micrococcus, Enterococcus and Staphylococcus were found to be the dominant bacterial genera in fermented rohu sauce. In summary, the fermentative conversion of the rohu into sauce is one of the effective methods for preservation and utilization of fish. The developed product should also applied as flavouring condiment in wide variety of sea-foods.

\section{References}

Amit, K. R., Jini, R., Swapna, H. C., Sachindra, N. M., Bhaskar, N., \& Baskaran, V. (2011). Application of Native Lactic Acid Bacteria (LAB) for Fermentative Recovery of Lipids and Proteins from Fish Processing Wastes: Bioactivities of Fermentation Products, Journal of Aquatic Food Product Technology, 20, 32-44. https://doi.org/10.1080/10498850.2010.528174

Amit, K. R., Swapna, H. C., Bhaskar, N., Halami, P. M., \& Sachindra, N.M. (2010). Effect of fermentation ensilaging on recovery of oil from fresh water fish viscera. Enzyme and Microbial Technology, 46(1), 9-13. https:/Doi.org/10.1016/j.enzmictec.2009.09.007

Aoshima, H., \& Ooshima, S. (2009). Anti-hydrogen peroxide activity of fish and soy sauce. Food Chemistry, 112, 339343.

https://doi.org/10.1016/j.foodchem.2008.05.069

APHA (2001). American Public Health Association Compendium of Methods for Microbiological Examination of Foods, 4th edn., Speak, M. L. Ed. Washington, USA

Bergey, D.H., Holt, J.G., Kreig, N.R., \& Sneath, P.H.A. (2002). Bergey`s manual of determinative bacteriology. Springer-Verlag, New York.

Bijinu, B., Binod, P., Amit, K.R., Suresh, P.V. Mahendrakar, N.S. \& Bhaskar, N. (2011). In vitro antioxidant and antibacterial properties of hydrolyzed proteins of delimed tannery fleshings: comparison of acid hydrolysis and fermentation methods. Biodegradation, 22, $287-$ 295. https://doi.org/10.1007/s10532-010-9398-0

Choksawangkarn, W., Phiphattananukoon, S., Jaresitthikunchai, J., \& Roytrakul, S. (2018). Antioxidative peptides from fish sauce by-products: Isolation and characterization. Agriculture and Natural Resources, 52, 460-466. https://doi.org/10.1016/j.anres.2018.11.001

Faisal, M., Islami, S.N.E., Islam, M.N., Kamal, M., \& Khan, M.N.A. (2015). Study on microbial and physical changes in fish sauce during fermentation. Research in 
Agriculture, Livestock and Fisheries, 2(2), 375-383. https://doi.org/10.3329/ralf.v2i2.25024

FAO (2018). The State of World Fisheries and Aquaculture 2018 - Meeting the Sustainable Development Goals.

Fukui, Y., Yoshida, M., Shozen, K., Funatsu, Y., Takano, T., Oikawa, H., Yano, Y., \& Satomi, M. (2012). Bacterial communities in fish sauce mash using culture-dependent and -independent methods. Journal of General and Applied Microbiology, 58, 273-281. https://doi.org/10.2323/jgam.58.273

Gediminas B.A., Olga, K.V., \& Jurgita, K. (2006). Food-protein enzymatic hydrolysates possess both antimicrobial and immunostimulatory activities: a cause and effect theory of biofunctionality. FEMS Immunology and Medical Microbiology, 46,131-138. https://doi.org/10.1111/j.1574-695X.2005.00019.x

Geis A.J., Singh, R., \& Teuber, M.J. (1983). Potential of lactic streptococci to produce bacteriocin. Applied and Environmental Microbiology, 45, 205-211.

Heo, S. J., Park, E. J., Lee, K. W., \& Jeon, Y. J. (2005). Antioxidant activities of enzymatic extracts from brown seaweeds. Bioresource Technology, 96, 1613-1623. https://doi.org/10.1016/j.biortech.2004.07.013

Hwanhlem, N., Buradaleng, S., Wattanachant, S., Benjakul, S., Tani, A., \& Maneerat, S. (2011). Isolation and screening of lactic acid bacteria from Thai traditional fermented fish (Plasom) and production of Plasom from selected strains. Food Control, 22, 401-407. https://doi.org/10.1016/j.foodcont.2010.09.010

Ibrahim, S.M. (2010). Utilization of Gambusia (Affinis affinis) for fish sauce production. Turkish Journal of Fisheries and Aquatic Sciences, 10, 169-172.

https://doi.org/10.4194/trjfas.2010.0202

Jiang, J.-J., Jeng, Q.-X., Zhu, Z.-W., \& Zhang, L.-Y. (2007). Chemical and sensory changes associated Yu-lu fermentation process- A traditional Chinese fish sauce. Food Chemistry, 104(4), 1629-1634. https://doi.org/10.1016/j.foodchem.2007.03.024

Jini, R., Swapna, H.C., Amit K. R., Vrinda, R., Halami P.M., Sachindra, N.M., \& Bhaskar, N. (2011). Isolation and characterization of potential lactic acid bacteria (LAB) from freshwater fish processing wastes for application in fermentative utilization of fish processing waste. Brazilian Journal of Microbiology, 42(4), 1516-1525. https://doi.org/10.1590/S1517-838220110004000039

Jung, J.Y., Lee, S.H., Lee, H.J., \& Jeon, C.O. (2013). Microbial succession and metabolite changes during fermentation of saeu-jeot: traditional Korean salted seafood. Food Microbiology, 34, 360-368.

https://doi.org/10.1016/j.fm.2013.01.009

Karparvar, N., Ghasemian Safaei, H., Derakhshandeh, A., Hemmati, F., \&Mazloomi, S.M. (2019). Isolation and identification of lactic acid bacteria from traditional fermented fish sauce (Mahyaveh) in Fars Province, Iran. International Journal of Nutrition Sciences, 4(1), 49-53. https://doi.org/10.30476/ijns.2019.81437.1005

Kehrer, J.P., \& Klotz, L.-O. (2015). Free radicals and related reactive species as mediators of tissue injury and disease: implications for health. Critical Review in Toxicology, 45(9), 765-798.

https://doi.org/10.3109/10408444.2015.1074159

Kilinc, B., Cakli, S., Tolasa, S., \& Dincer, T. (2006). Chemical microbiological and sensory changes associated with fish sauce processing. European Food Research and Technology, 222, 604-613. https://doi.org/10.1007/s00217-005-0198-4

Lambert, J.D., \& Yang, C.S. (2003). Mechanisms of cancer prevention by tea constituents. Journal of Nutrition, 133, 3262S-3267S.

https://doi.org/10.1093/jn/133.10.3262S

Longfils, P., Monchy D., Weinheimer, H, Chavasit, V, Nakanishi, Y., \& Schümann, K. (2008). A comparative intervention trial on fish sauce fortified with NaFe-EDTA and FeSO4+citrate in iron deficiency anemic school children in Kampot, Cambodia. Asia Pacific journal of clinical nutrition. 17(2), 250-257.

https://doi.org/10.6133/apjcn.2008.17.2.10

Lee, S.H., Jung, J.Y., \& Jeon, C.O. (2015). Bacterial community dynamics and metabolite changes in myeolchi-aekjeot, a Korean traditional fermented fish sauce, during fermentation. International Journal of Food Microbiology, 203, 15-22.

https://doi.org/10.1016/j.ijfoodmicro.2015.02.031

Lopetcharat, K., \& Park, J. (2002). Characteristics of fish sauce made from Pacific whiting and surimi by-products during fermentation stage. Journal of Food Science, 67(2), 511516. https://doi.org/10.1111/j.1365-2621.2002.tb10628.x

Lowry, O.H., Rosebrough, N.J., Farr, A.L., \& Randall, R.J. (1951). Protein measurement with Folin phenol reagent. Journal of Biological Chemistry, 193, 265-275.

Majumdar, R.K., Bejjanki, S.K., Roy, D., Shitole, S., Saha, A., \& Narayan, B. (2015). Biochemical and microbial characteristics of Ngari and Hentaak - traditional fermented fish products of India. Journal of Food Science and Technology, 52(12), 8284-8291. https://doi.org/10.1007/s13197-015-1978-x

Majumdar, R.K., Roy, D., Bejjanki, S., Shitole, S., \& Bhaskar, N. (2016). Chemical and microbial properties of shidal, a traditional fermented fish of northeast India. Journal of Food Science and Technology, 53(1), 401-410. https://doi.org/10.1007/s13197-015-1944-7

Marti-Quijal, F.J., Remize, F., Meca, G., Ferrer, E., Ruiz, M-J., \& Barba, F.J. (2020). Fermentation in fish and by-products processing: an overview of current research and future prospects. Current Opinion in Food Science, 31, 9-16. https://doi.org/10.1016/j.cofs.2019.08.001

Paludan-Muller, C., Madsen, M., \& Sophanodora, P. (2002). Fermentation and micro flora Plaa-som, a Thai fermented fish product prepared with different salt concentrations. International Journal of Food Microbiology, 73(1), 61-70. https://doi.org/10.1016/S0168-1605 (01)00688-2

Peralta, E., Hatate, H., Kawabe, D., Kuwahara, R., Wakamatsu, S., \& Murata, H. (2008). Improving antioxidant activity and nutritional components of Philippine salt-fermented shrimp paste through prolonged fermentation. Food Chemistry, 111(1), 72-77. https://doi.org/10.1016/j.foodchem.2008.03.042

Prieto, P., Pineda, M., \& Aguilar, M. (1999). Spectrophotometric quantification of antioxidant capacity through the formation of a phosphomolybdenum complex: specific application to the determination of vitamin E. Analytical Biochemistry, 269(2), 337-341.

https://doi.org/10.1006/abio.1999.4019

Sachindra, N.M. \& Bhaskar, N. (2008). In-vitro antioxidant activity of liquor from fermented shrimp biowaste. Bioresource Technology, 99, 9013-9016. https://doi.org/10.1016/j.biortech.2008.04.036 
Siddegowda, G.S., Bhaskar, N., \& Shubha Gopal. (2016). Bacteriological properties and health related biochemical components of fermented fish sauce: An overview. Food Reviews International, 32(2), 203-229. https://doi.org/10.1080/87559129.2015.1057844

Siddegowda, G.S., Bhaskar, N., \& Shubha Gopal. (2016). Biochemical and bacteriological quality of rohu (Labeo rohita) head sauce produced by enzymatic and fermentation method. Fishery Technology, 53, 220-231.

Siddegowda, G.S., Bhaskar, N., \& Shubha Gopal. (2017). Fermentative properties of proteolytic Pediococcus strains isolated from salt fermented fish hydrolysate prepared using freshwater fish rohu (Labeo rohita). Journal of Aquatic Food Product Technology, 26(3), 341355.

https://doi.org/10.1080/10498850.2016.1185754

Udomsil, N., Rodtong, S., Tanasupawat, S., \& Yongsawatdigul, J. (2015). Improvement of fish sauce quality by strain CMS5-3-1: a novel species of Staphylococcus sp. Journal of Food Science, 80(9), M2015-M2022. https://doi.org/10.1111/1750-3841.12986

Vidanarachchi, J.K., Ranadheera, C.S., Wijarathen, T.D., Udayangani, R.M.C., Himali, S.M.C. and Pickova, J. (2014). Application of seafoods byproducts in the food industry and human nutrition. In: Seafood processing by products: Trends and Applications. Kim SK (Ed). Springer, USA, pp 463-528.

Xu, W., Yu, G., Xue, C., Xue, Y., \& Ren, Y. (2008). Biochemical changes associated with fast fermentation of squid processing by-products for low salt fish sauce. Food Chemistry, 107, 1597-1604.

https://doi.org/10.1016/j.foodchem.2007.10.030

Yongsawatidigul, J., Rodtong, S., \& Raksakulthai, N. (2007). Acceleration of Thai fish sauce fermentation using proteinases and bacterial starter culture. Journal of Food Science, 72(9), M382-M390. https://doi.org/10.1111/j.1750-3841.2007.00532.x

Zang, J., Xu, Y., Xia, W., \& Regenstein, J.M. (2019). Quality, functionality, and microbiology of fermented fish: a review, Critical Reviews in Food Science and Nutrition, DOI: 10.1080/10408398.2019.1565491 https://doi.org/10.1080/10408398.2019.1565491

Zarei, M., Najafzadeh, H., Eskandari, M.H., Pashmforoush, M., Enayati, A., Gharibi, D., \& Fazlara, A. (2012). Chemical and microbial properties of mahyaveh, a traditional Iranian fish sauce. Food Control, 23(2), 511-514. https://doi.org/10.1016/j.foodcont.2011.08.023 